\title{
Landslide Investigations Using the geoelectrical Scanning Method and Ground Penetrating Radar - case Studies
}

\author{
FILIP D. ARNAUT, University of Belgrade, \\ Faculty of Mining and Geology, Belgrade \\ BRANISLAV B. SRETENOVIĆ, University of Belgrade, \\ Faculty of Mining and Geology, Belgrade
}

\author{
Professional paper \\ UDC: 624.131.537(497.11) \\ $550.8 .08(497.11)$ \\ DOI: 10.5937/tehnika2104419A
}

\begin{abstract}
Geotechnical investigations of landslides for future mitigation are a complex task. To obtain relevant information, various geophysical methods are used, with varying degrees of success. The geoelectrical scanning method, also known as Electrical Resistivity Tomography (ERT) has been successfully applied in several locations in Serbia in the las three decades. The geoelectrical scanning method was used during investigations of landslides: Umka, Lukovska banja, Tara, and Trandžament, while both geoelectrical scanning and Ground Penetrating Radar (GPR) were utilized at the Trandžament landslide. The achieved results from both methods are mutually correlated at the Trandžament landslide. Correlation of GPR data with geoelectrical scanning data was only possible since there were no nearsurface low resistivity zones in the Trandžament landslide body. Otherwise, electromagnetic signal attenuation would be high in the presence of near-surface low resistivity zones, and a quality signal would be impossible to detect at the receiving antenna.
\end{abstract}

Key words: Electrical Resistivity Tomography (ERT), Ground Penetrating Radar (GPR), Landslide geophysical surveys

\section{INTRODUCTION}

Landslides are a phenomenon that can be categorized in a variety of ways, the most common being according to landslide activity, rate of movement, water content, material and type of movement [8]. From a geophysical standpoint, two important aspects can be singled out- sliding surface and the contrast between the sliding mass and bedrock. The first aspect can be subdivided into a unique slide surface or a zone with several sliding surfaces, while the second one is based on the physical and mechanical properties of the sliding mass, sliding surface, bedrock and groundwater distribution.

In this research paper, two main types of landslides are presented - Landslides in Neogene sediments (mainly clays, marls and sands) at the brim of the Panonian basin, and landslides in deluvial material that lie over older Mesozoic and Paleozoic bedrock.

Author's address: Filip Arnaut, University of Belgrade, Faculty of Mining and Geology, Belgrade, Đušina 7

e-mail: G601-20@rgf.bg.ac.rs

Paper received: 21.04.2021.

Paper accepted: 11.08.2021.
Further surveys in the Neogene sediments enabled the discovery of two forms of landslides - Landslides on the right riverbank of the Sava and Danube River and, landslides in Central Serbia (inland Neogene) [1].

Landslides on the right riverbank of the Sava and Danube River are formed in clay and marl weathering zones and slide over undisturbed sediments. There is a distinct sliding zone. In terms of hardness and water content, there are major differences between the sliding mass and the bedrock. The Umka landslide is one of the most representative landslides that form on the right riverbank of the Sava and Danube River [1]. The Umka landslide was investigated by various geotechnical, geophysical and geological methods and extensive data was collected [1]. Investigation by permanent GNSS monitoring categorized the Umka landslide as slow to very slow [5].

The second type of landslide is distinguished by significant variations in composition, physical, and mechanical properties between the sliding mass and the bedrock. The consolidated bedrock, which is mainly made up of crystalized slates, limestones, and flysch (landslides „Tara“ and „Lukovska banja“), slides over the clay mass, which includes more or less fragments of the bedrock [7]. 


\section{METHODOLOGY}

In this study are presented results of two well-known geophysical methods already applied on aforementioned landslides: Electrical Resistivity Tomography (ERT) and Ground Penetrating Radar (GPR).

The direct current resistivity method can be performed as 1D resistivity sounding, 2D investigations also known as electrical resistivity tomography or 3D technique. It is a conventional geophysical method that uses two current and two potential electrodes. Current electrodes inject direct current into the subsurface, and potential electrodes measure the resulting potential difference. Measurements can be taken inline (1D and 2D measurements) or over an area (3D measurements), and the results can be graphically shown as sounding curves or pseudosections of apparent resistivity [9] or apparent resistivity maps.

The electromagnetic reflective method (ERM), often known as ground penetrating radar, is used to study structures at relatively small depths. The GPR method relies on the reflection of high-frequency electromagnetic waves ( $8 \mathrm{MHz}$ to $4 \mathrm{GHz}$ ) at various subsurface medium boundaries, where the dielectric constant (permittivity) and resistivity change. While conducting GPR investigations, depth of penetration and resolution have to be taken into account. Higher transmitter antenna frequency yields better resolution, on the other hand, lower frequency increases the depth of penetration [3].

\section{CASE STUDIES}

\subsection{Landslide ,Umka“}

Umka is a Belgrade suburb that stretches for a few kilometers along the Sava River. The entire estate is built on top of a landslide that has varying depths to slip surface (block structure) [1], which causes pro- blems such as house and road collapse. The landslide has also impacted the local road that connects Belgrade and Obrenovac. Due to the presence of a landslide that could not be mitigated, the newly planned road had to be rerouted to the other side of the Sava River. ERT measurements were conducted du-ring the geotechnical investigation of the landslide zo-ne Umka and Duboko for the preliminary design of the E-76 BelgradeObrenovac highway (1991/1992). The ERT profiles had a total length of 2 kilometers [1,2].

The Umka landslide is one of the most investigated landslides in Serbia. Various methods (permanent GNSS monitoring, photogrammetry, geotechnical and geophysical investigations, boreholes and explorations shafts etc), have been employed by $[1,2,5]$, in order to characterize the landslides causative and triggering factors, overall geometry etc. Research by [1] dis-played that the Umka landslide is a slow to very slow landslide with a reactivation period of several years to several decades.

Even though the sliding zone is distinct, and the differences in geotechnical properties (hardness and water content) between the sliding mass and the bedrock are large, an essential physical property (resistivity contrast) is relatively small (2.5: 1$)$. In those circumstances, the geoelectrical scanning method's performance was debatable.

The scanning profile and the exploration shaft (located on the „A Block“" of the Umka landslide [1]) is depicted in Figure 1. The ap-parent resistivities calculated in the nearby exploration shaft show a strong correlation with the $2 \mathrm{D}$ inter-pretation. This form of study shows the presence of zo-nes with even lower resistivity values (around $2 \Omega \mathrm{m}$ at the 50th and 60th meter) than the zone associated with water leakage in the exploration shaft (around $4.5 \Omega \mathrm{m}$ ).

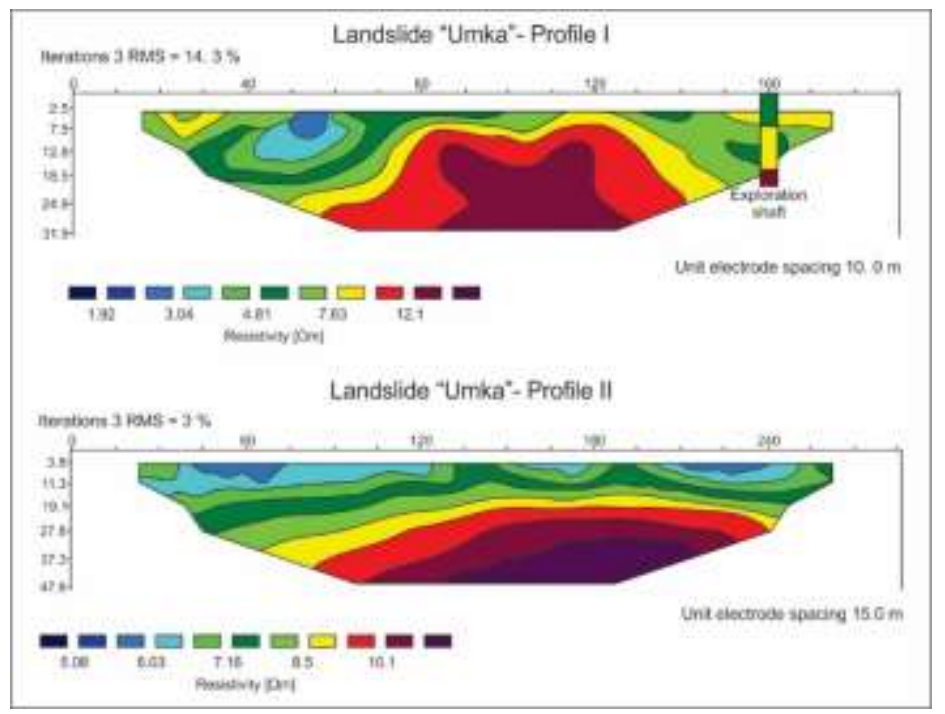

Figure 1 - Results of 2D inversion of ERT data at ,Umka“ landslide [7] 
In comparison to conventional geotechnical methods such as boreholes and exploration shafts, the 2D interpretation of the geoelectrical scanning method provided valuable experience that successfully demonstrated the application of the geoelectrical scanning method, which showed improved survey area coverage (2.2 kilometres were scanned) while also significantly reducing survey expense.

\subsection{Landslide „Lukovska Banja“ and ,,Tara“}

The second type of landslide is described by significant differences in composition, physical, and mechanical properties between the sliding mass and bedrock. The clay mass, which includes bedrock fragments, slides along the solid bedrock in this case. The geoelectrical scanning method was used to survey these two types of landslides along parallel profiles, which helped with the assessment of 2D model divergence during inversion.

The geological structure of the landslide „Lukovska banja“ (figure 2) is com-plex. The landslide's body is made up of fragments of marly, sha-ly limestones, marls, metasandstone, clayey, and chlo-rite-sericite shales.

The presence of a 3D block of rock with a volume of up to $10 \mathrm{~m}^{3}$ was discovered using geological mapping and borehole data. The landslide's bedrock is serpentinite, as well as metamor-phosed peridotites, shaley limestones, clays, and marls.

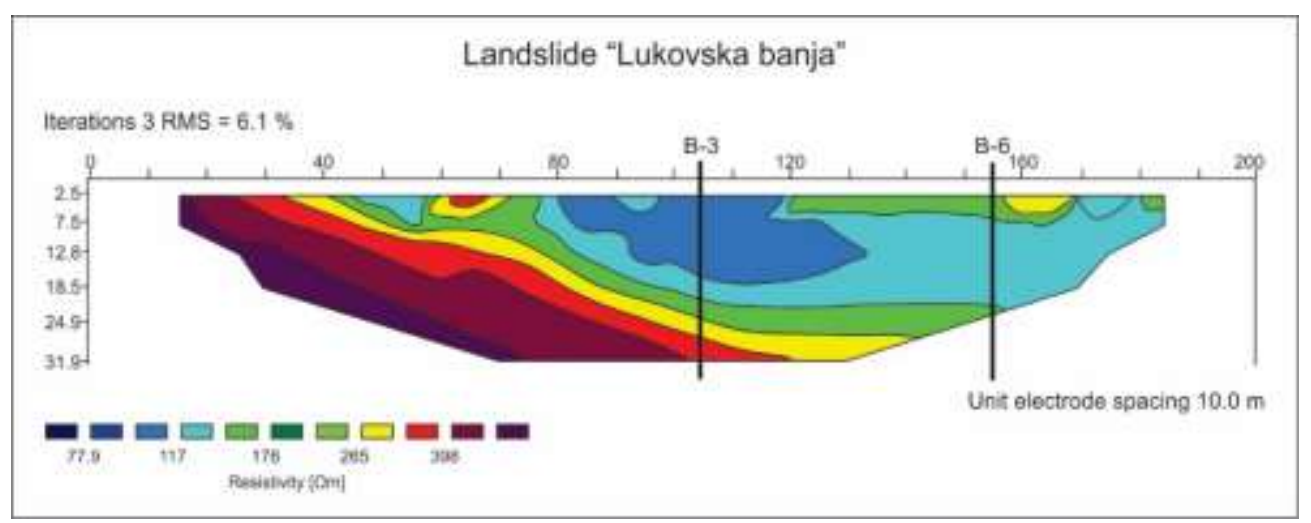

Figure 2 - Result of 2D inversion of ERT data at "Lukovska banja" landslide [7]

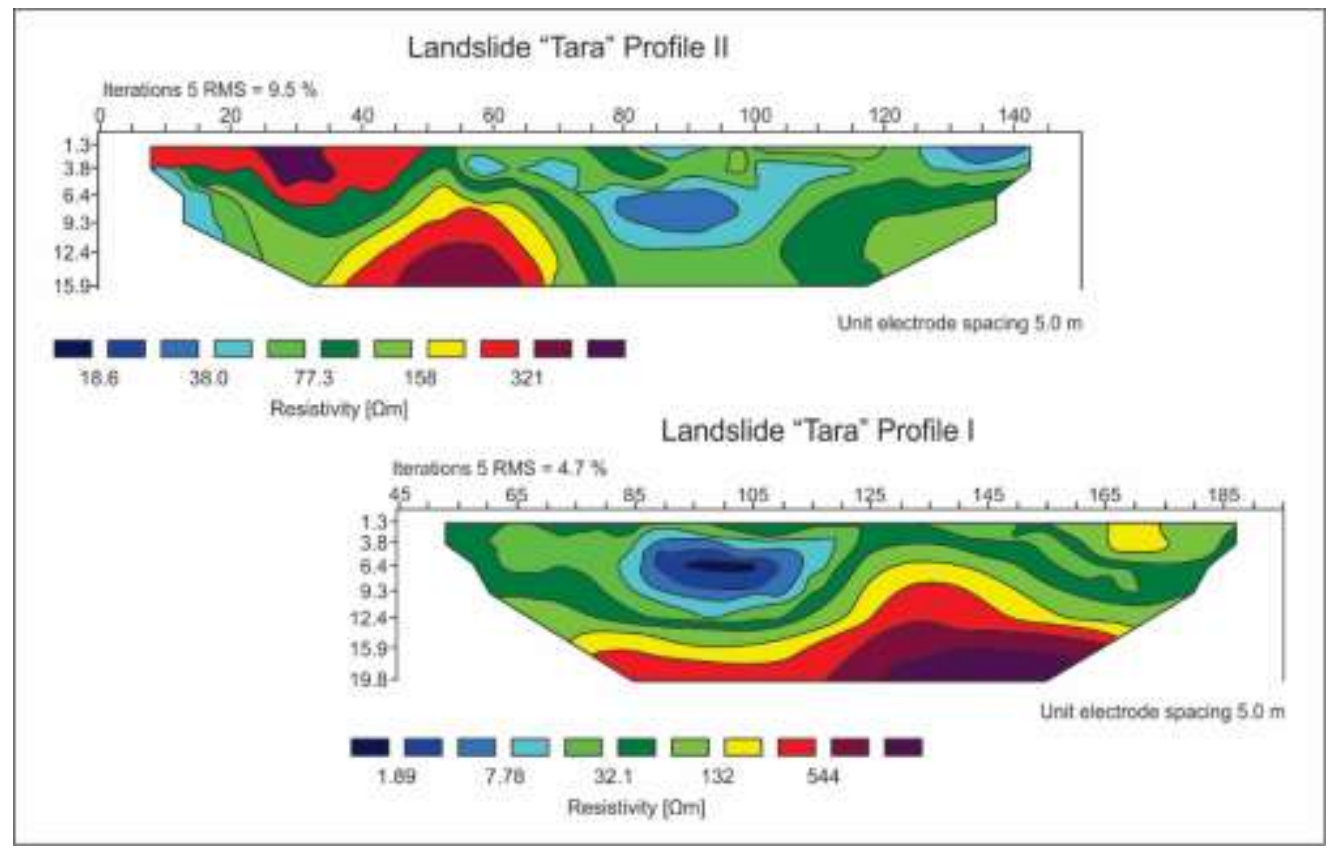

Figure 3 - Result of 2D inversion of ERT data at "Tara" landslide [7]

The landslide „Tara“" was surveyed during its remediation (figure 3), that is, when a concrete retaining wall was installed. The survey's aim was to check the depth to the bedrock, which had already been estimated prior. The fresh concrete injected during the measurement period is most likely to blame for the exceptionally low resistivity values on profile I. Under the road, profile I was measured at the same level as the concrete injection site, but five meters below profile II. The retaining wall's founding quality was 
determined by measurements. Zones of low apparent resistivity can be seen (from the 125th meter) outside the landslide zone. In order to reduce the impact of topography, Profile II was located on the road over the landslide on the side away from the landslide. When taking into account that profile I began at the 45th meter of profile II, a good correlation with profile I can be made. Since profile II is closer to the landslide scar, the depth to the bedrock is lower. The achieved rootmean-square error is 9.5 percent, which is consistent with topography's effect on measurements.

A preview of the „Umka“, „Lukovska banja“ and „Tara" landslides is also given in [6] and [7]

\subsection{Landslide "Trandžament “}

Since the landslide occurred along a road underneath the Petrovaradin fortress, various materials (gravel, slag, etc.) were used as a filling to keep the road working, this landslide could also be viewed as a wild waste dump. Low resistivity marls provide a strong geological basis for GPR surveys when a high resi-stivity surface layer is present. A $500 \mathrm{MHz}$ antenna was used to perform the GPR surveys. The landslide „Trandžament" is situated on the ro-ad underneath Petrovaradin fortress. The formation is thought to have been aided by a drainage system that drains excess water from the fortress to the Danube. This drainage system, which is 1 meter in diameter and runs beneath the road, dates from the Austro- Hun-garian Empire. Since the drainage system is made of bricks, it leaks and creates an unstable zone around it when a greater amount of water passes in. Filling the road with slag and gravel has been undertaken for years in order to keep the road in good shape.

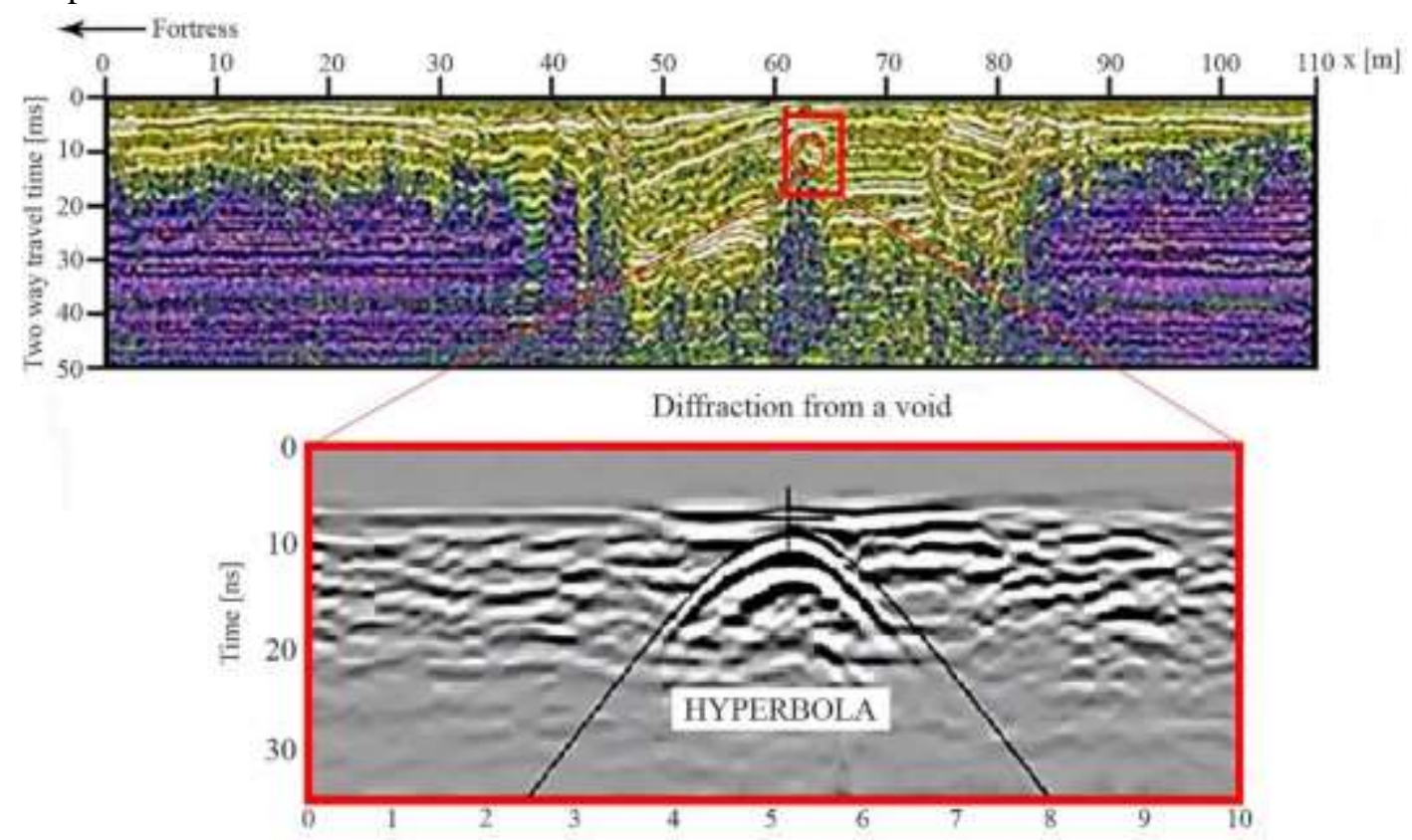

Figure 4 - GPR survey in the Trandžament landslide zone
A GPR and geoelectrical survey were conducted to prove the hypothesis about the landslide's causative and triggering factors. Given the relatively high resistivity values of the surface layer and the low resistivity values of the drainage system with water and the underlying clay and marl layers, it was believed that the drainage system full of water would be a good target for GPR investigations. In comparison to the GPR survey, geoelectrical scanning has good survey resolution, so identification of the wet zone and a deeper depth of investigation were expected.

Geoelectrical scanning measurements were taken along two parallel profiles, each 125 meters long, on the left and right sides of the road. There were 26 electrodes, with a unit electrode spacing of 5 meters, and six depth levels, allowing for a depth of investigation of around 15 meters. The drainage system was located in the center of the profile.

A $500 \mathrm{MHz}$ antenna was used to conduct a GPR survey from a vehicle along a profile line that was a few kilometers long. The vehicle was moving along the road, closer to the Danube River and profile II of geoelectrical scanning. Figure 4 shows a GPR section of the landslide, as well as the position of the hyperbolic reflection caused by diffraction from the drainage system. There is significant electromagnetic attenuation in the drainage region, in contrast to the areas of high resistivity filled material. Similarly, from the 38th to the 43rd meter of the GPR section, multiple reflections can be seen that expand along the entire section with a decrease in amplitude. These multiple refle-ctions reveal good reflectors in the area around the antenna, i.e., near the asphalt lane. 
The 2D model obtained with geoelectrical scanning along profile I, which is closer to the fortress, is shown in the upper part of figure 5.

A low resistivity zone was detected in the middle of the profile, which may indicate the position of the damp zone around the drainage system, while a high resistivity zone was de-tected above the drainage system, which reflects the filled material. The attenuation anomaly zone (62nd meter of the section at 1.5meter depth) at the position of high resistivity materials that allow quality refle-ctions is also visible in the GPR section. The overall geometry of the filled material as well as the landslide is determined using geoelectrical scanning method.

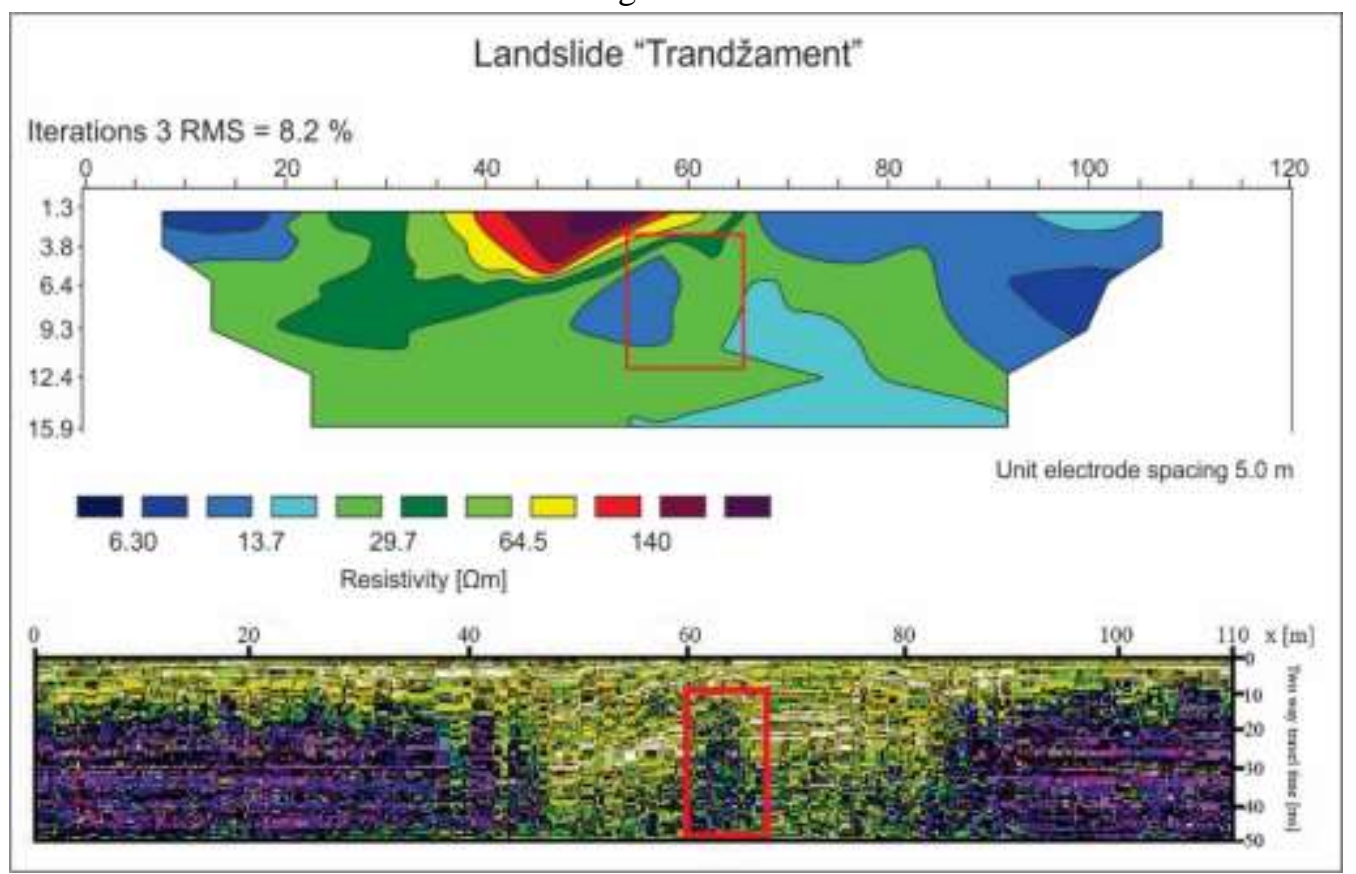

Figure 5 - Results of GPR and ERT surveys along profile I

Figure 6 shows a comparison of geoelectrical scanning profile II and the GPR section. Since the GPR section and the geoelectrical scanning profile are closer together, a better correlation in the form of the length and geometry of the filled material can be esta- blished. Geoelectrical scanning, like the previous example, provides a better depth of investigation and overall geometry, especially in low resistivity clayey marls. The electromagnetic signal was completely attenuated in those zones, in comparison.

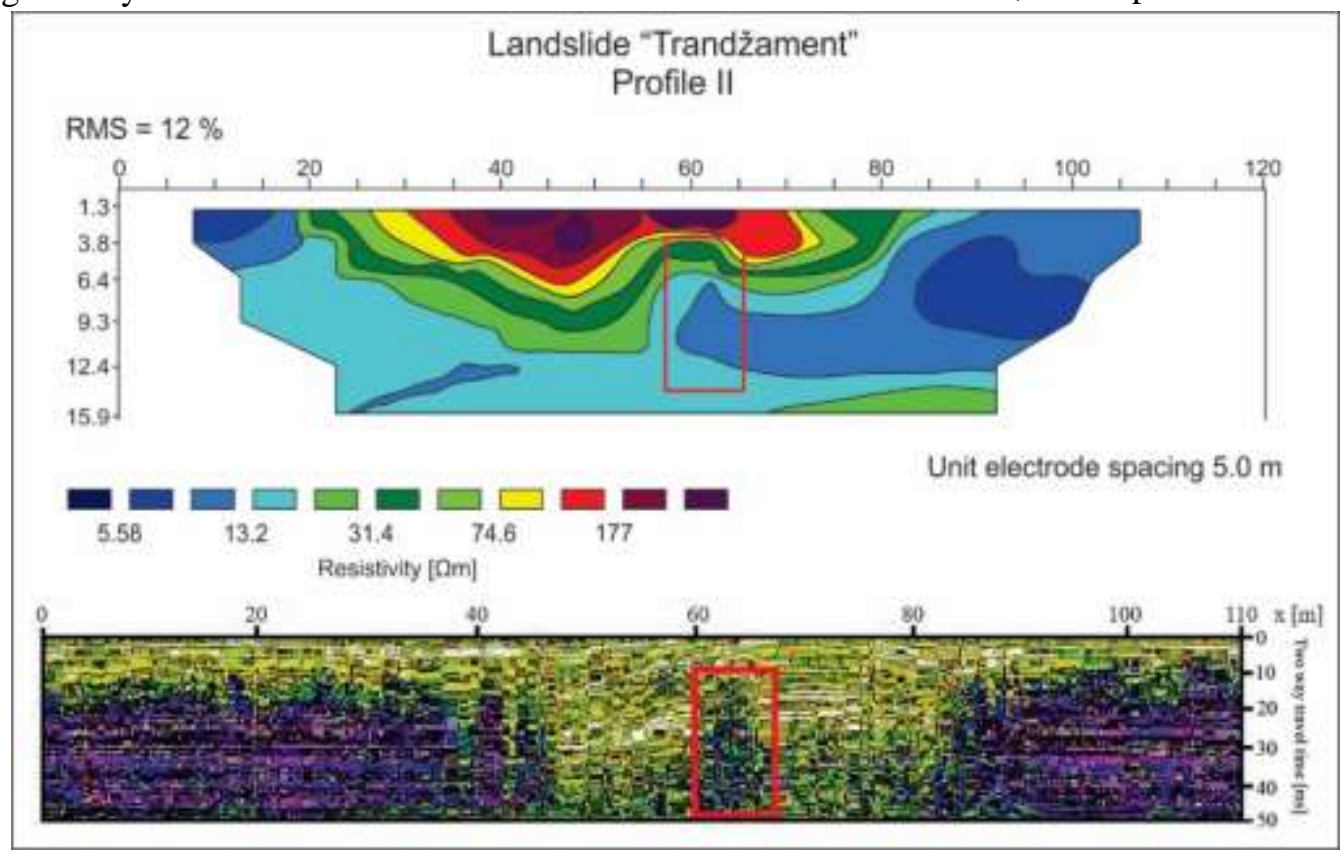

Figure 6 - Results of GPR and ERT surveys along profile II 
The landslide extends along profile II (figure 6) from the 20th to the 80th meter, with a maximum depth of about 10 meters. At the end of the profile, the resistivity values decrease with depth as well as laterally. In other words, the lower resistivity values in the right part of the profile decrease to $6 \Omega \mathrm{m}$. It's worth noting that the geoelectrical scanning results are skewed by lateral and topography effects. This was reflected in the RMS value, which was $8 \%$ for profile I and $12 \%$ for profile II. The existence of 3D inhomogeneities did play a role in the deviation from $2 \mathrm{D}$ conditions. The topography effects are caused by notches on both sides of the road, which strike in a relatively gradual pattern along the longest part of the geoelectrical scanning profiles.

\section{DISCUSSION AND CONCLUSION}

A multi-geophysical approach should be used when dealing with a complex subsurface structure such as landslides. GPR and ERT measurements provide additional data that can substantially aid in the interpretation process and provide valuable insight into the subsurface architecture, which can further complement geotechnical data. Even when dealing with extremely attenuated GPR sections, by correlating them with ERT profiles, some useful near-surface information can be retrieved, as illustrated in [4]. When dealing with landslides, high density data acquired quickly is preferable [3]. Another advantage of integrating GPR and ERT data is the lower investigation cost compared to other investigation methods (boreholes, exploration shafts etc.).

The Umka landslide demonstrated that without supplementary data such as exploration shafts, boreholes, or other geotechnical or geophysical data, the ERT method could be debatable even when the sliding zone is distinct, but the resistivity contrast is low. Furthermore, the Umka landslide demonstrated that in order to completely identify such a complex geological setting, a multidisciplinary approach and a variety of methods should be used. The extensive data collected from permanent monitoring stations is quite useful. This would also apply to continuous monitoring using the ERT method at various times of the year.

The Lukovska banja landslide revealed useful information on the landslide's composition when ERT was cross-referenced with geological mapping and drilling data. The approximation of the bedrock volume was made possible due to additional data.

Landslide Tara revealed a high correlation be-tween the two parallel ERT profiles, but also demonstrated that topography has an effect on measurements (increased RMS value of 9.5 percent) and should be considered.
2D geoelectrical surveys are successfully correlated with ground penetrating radar surveys in the absence of near-surface low resistivity zones („Trandžament" landslide). Ground penetrating radar surveys have a limited depth of investigation due to signal attenuation in low resistivity zones. Topography had a non-negligible effect in the RMS error in the Trandžament landslide, as well in the Tara landslide case. Apart from the topography effect, the presence of 3D inhomogeneities also contributed to the deviations from 2D conditions, hence increasing the RMS error value.

GPR will never be the first choice in landslide studies when other geophysical methods are available, as [4] noted, but it has proven to be a valuable auxiliary (supplementary) method. The 2D electrical imaging technique offers satisfactory results when dealing with various engineering geology problems, and, because of its relatively low cost and fast acquisition time, should accompany geotechnical data.

\section{REFERENCES}

[1] Abolmasov B, Milenković S, Marjanović M, Đurić U. and Jelisavac B, A geotechnical model of the Umka landslide with reference to landslides in weathered Neogene marls in Serbia. Landslides, 12(4), pp.689-702, 2015.

[2] Đurić U, Kvantitativna procena rizika od klizišta Umka kod Beograda. Doktorska disertacija, Univerzitet u Beogradu, Rudarsko- geološki fakultet. p 254, 2020.

[3] Ristić A, Abolmasov B, Govedarica M, Petrovački D. and Ristić A, Shallow-landslide spatial structure interpretation using a multi-geophysical approach. Acta Geotechnica Slovenica, 9(1), pp.47-59, $2012 .$.

[4] Sass O, Bell R. and Glade T, Comparison of GPR, 2D-resistivity and traditional techniques for the subsurface exploration of the Öschingen landslide, Swabian Alb (Germany). Geomorphology, 93(1-2), pp.89-103, 2008.

[5] Samardžić-Petrović M, Popović J, Đurić U, Abolmasov B, Pejić M. and Marjanović M, Permanent GNSS monitoring of landslide Umka. In XIV International Conference On Contemporary Theory And Practice In Construction XIV Stepgrad XIV Proceedings, 2020. University of Banja Luka Faculty of Architecture, Civil Engineering and Geode, 2020..

[6] Sretenović B, Marčetić D, Determination of the internal geometry of a landslide using electrical tomography. 54 $4^{\text {th }}$ Meeting of the EAEG: Paris, France pp. 354-355, 1992. 
[7] Sretenović B, Lokin P. i drugi, Some possibilities of electrical scanning method in landslide exploration, $6^{\text {th }}$ Meeting of Environmental and Engineering Geophysics, September 3-7,2000, Bochum-Germany, 2000 .

[8] Varnes D. J. and Cruden, D. M, Landslide types and processes. Landslides: investigation and mitigation,
Transportation Research Board special report, 247, 1996.

[9] Zhou B. and Kanl I, Electrical resistivity tomography: a subsurface-imaging technique. In Applied geophysics with case studies on environmental, exploration and engineering geophysics. London, UK: IntechOpen.

\section{REZIME}

\section{ISTRAŽIVANJE KLIZIŠTA METODAMA GEOELEKTRIČNOG SKENIRANJA I GEORADARA - NEKI PRIMERI}

Istraživanje klizišta u cilju projektovanja sanacionih mera predstavlja kompleksan geotehnički zadatak. Pri tome, različite geofizičke metode se koriste radi dobijanja relevantnih podataka sa različitim stepenom uspeha. U prethodne tri decenije, metoda geoelektričnog skeniranja je uspeřno primenjena tokom istraživanja većeg broja klizišta. U radu su prikazane studije slučaja klizišta: Umka, Lukovska banja, Tara i Trandžament, metodom geoelektričnog skeniranja i elektromagnetometrijskom metodom (georadar). Dobijeni rezultati obe metode su međusobno korelisani na primeru klizišta Trandžament. Iako georadarska metoda ima relativno male vrednosti dubinskog zahvata, korelacija je bila omogućena u slučaju nedostatka bliskopovršinskih niskootpornih zona (klizište Trandžament). U slučaju prisustva bliskopovršinskih niskootpornih zona, atenuacija elektromagnetnih signala je bila prevelika za dobijanje kvalitetnog korisnog signala na prijemnoj anteni.

Ključne reči: Metoda geoelektričnog skeniranja (ERT), georadar (GPR), istraživanje klizišta 